\title{
Using Plant-Based Preparations to Protect Common Bean against Halo Blight Disease: The Potential of Nettle to Trigger the Immune System
}

\author{
Alfonso Gonzalo De la Rubia ${ }^{1}$, María De Castro ${ }^{2}$, Inés Medina-Lozano ${ }^{3,4}$ (D) and Penélope García-Angulo ${ }^{1, * \mathbb{D}}$ \\ 1 Área de Fisiología Vegetal, Departamento de Ingeniería y Ciencias Agrarias, Universidad de León, \\ 24071 Leon, Spain; algor@unileon.es \\ 2 Laboratorios Analíticos Agrovet, Camino Caserío Santovenia, Mansilla Mayor, 24217 Leon, Spain; \\ fisicoquimica@agrovet.es \\ 3 Centro de Investigación y Tecnología Agroalimentaria de Aragón (CITA), Unidad de Hortofruticultura, \\ Avda. Montañana 930, 50059 Zaragoza, Spain; imedina@cita-aragon.es \\ 4 Instituto Agroalimentario de Aragón-IA2 (CITA-Universidad de Zaragoza), 50013 Zaragoza, Spain \\ * Correspondence: pgara@unileon.es
}

Citation: De la Rubia, A.G.; De Castro, M.; Medina-Lozano, I.;

García-Angulo, P. Using Plant-Based Preparations to Protect Common Bean against Halo Blight Disease: The Potential of Nettle to Trigger the Immune System. Agronomy 2022, 12, 63. https://doi.org/10.3390/ agronomy12010063

Academic Editors: Marie France Corio-Costet and Maria Céu Lavado da Silva

Received: 11 November 2021 Accepted: 23 December 2021 Published: 28 December 2021

Publisher's Note: MDPI stays neutral with regard to jurisdictional claims in published maps and institutional affiliations.

Copyright: (c) 2021 by the authors. Licensee MDPI, Basel, Switzerland. This article is an open access article distributed under the terms and conditions of the Creative Commons Attribution (CC BY) license (https:// creativecommons.org/licenses/by/ $4.0 /)$.

\begin{abstract}
Halo blight disease of beans (Phaseolus vulgaris L.), caused by the bacterium Pseudomonas syringae pv. phaseolicola (Pph), is responsible for severe losses in crop production worldwide. As the current agronomic techniques used are not effective, it is necessary to search for new ones which may prevent disease in common bean. In this study, we challenged four plant-based preparations (PBPs), with no other agronomic uses, as they come from industrial waste (grapevine pomace $\left(\mathrm{R}_{\mathrm{G}}\right)$ and hop residue $\left(\mathrm{R}_{\mathrm{H}}\right)$ ) or wild plants (Urtica dioica $(\mathrm{U})$ and Equisetum sp. (E)), to be used as immune defense elicitors against $\mathrm{Pph}$ in common bean. After studying their inhibitory effect against Pph growth by bioassays, the two most effective PBPs $\left(R_{G}\right.$ and $\left.U\right)$ were applied in common bean plants. By measuring the total $\mathrm{H}_{2} \mathrm{O}_{2}$, lipid peroxidation, and antioxidant enzymatic activities, as well as the expression of six defense-related genes-PR1, WRKY33, MAPKK, RIN4, and PAL1-, it was observed that U-PBP application involved a signaling redox process and the overexpression of all genes, mostly PR1. First infection trials in vitro suggested that the application of U-PBP involved protection against Pph. The elicitation of bean defense with U-PBP involved a decrease in some yield parameters, but without affecting the final production. All these findings suggest a future use of U-PBP to diminish halo blight disease.
\end{abstract}

Keywords: by-product; residue; crop protection; biotic stress; common bean; Pseudomonas syringae; Urtica dioica; grapevine pomace

\section{Introduction}

Plant diseases, caused by bacterial pathogens, are responsible for severe crop losses in production worldwide. In the case of common bean, halo blight disease results firstly in critical economic problems for farmers and in difficulties for breeding in certain areas where this legume has become the only protein source. Halo blight is produced by Pseudomonas syringae pv. phaseolicola (Pph) — a biotrophic gamma-proteobacteria-[1,2]. This disease causes yield losses of up to $45 \%$ [3], and its main symptoms are general chlorosis of the leaves, stunting, and distortion of growth [2]. The control of the disease usually consists in growing healthy seeds every season or using varieties with increased genetic resistance. The latter control method is not an option when the susceptible variety has gastronomical and economic interest. The only chemical treatments are based on copper formulations, of limited application at the flowering stage, when symptoms can only be reduced, but not eliminated [2]. Moreover, some copper-resistant strains have been documented [4]. Consequently, it is necessary to make an effort to research new agronomical 
techniques or protocols that prevent disease in beans or at least diminish symptoms and losses, as the ones currently used are not totally effective.

Recently, a variety of common beans, called Riñón, was described as Pph-susceptible [5,6]. Although this variety initiates defense responses, the expression of defense-related genes, the activation of an effective antioxidant system and, the phytohormone signaling are limited. However, the immune system of this variety can be activated by the salicylic acid structural analog 2,6-dichloroisonicotinic acid (INA) [7-9]. The activation of the immune system prior to pathogen attack, which primes plant defense for a concomitant infection (known as elicitation), can be achieved by the application of chemical compounds, such as INA [10], the nonprotein amino acid $\beta$-aminobutyric acid (BABA [11]) or benzothiadiazole (BTH [12]), but also by natural compounds. Since during plant-pathogen interaction, many damage-signaling molecules (damage-associated molecular patterns, DAMPs) are released from host cells due to pathogen activity, mainly from the cell wall [13-15], it has been studied that their application prior to infection activates defensive pathways, protecting the plants [16-19]. As the source of these new elicitors are plants themselves, this opens the possibility to study new plant-based products (PBPs) with the potential for protecting crops. During biotic stresses, DAMPs released to the apoplast and the apparition of Pathogen-associated molecular patterns (PAMPs) induce the production of reactive oxygen species (ROS), such as hydrogen peroxide $\left(\mathrm{H}_{2} \mathrm{O}_{2}\right)$ [20]. Most of this $\mathrm{H}_{2} \mathrm{O}_{2}$ is produced in the apoplast by means of superoxide dismutase (SOD), plasma membrane NADPH oxidases, and type III peroxidases ([21] and references therein). Once inside the cell, the $\mathrm{H}_{2} \mathrm{O}_{2}$ is removed by catalase (CAT) and ascorbate peroxidase (APOX) or can also be used for oxidizing cysteine residues of specific target proteins that can induce other cytoplasmic receptors or the mitogen-activated protein kinase (MAPK) cascade, that finishes with the activation of transcription factors [13]. Finally, a deep transcriptional reprogramming that activates all mechanisms that conform to the immune response is initiated [20].

For years, traditional agriculture has used raw organic materials to protect crops, without full knowledge of their way of action. Several studies have suggested that some of them could function as antibiotics [22-27]. The reason is that plants can synthesize a great amount of different secondary metabolites such as alkaloids, flavonoids, and phenolics with the potential to combat pathogens and their metabolites [28]. On the other hand, it has been noticed that some plants or extracts from them can function as biostimulants, promoting growth or activating defensive mechanisms against different stresses. Examples of plants used as extracts to promote yield are mentha and oregano, which protect tomato plants against Fusarium oxysporum and Verticillium dahlia [29]; Ulva rigida extracts, which improve salinity tolerance in wheat [30]; Vernonia amygdalina leaf extract, that can be used to control gray mold disease also on tomato [31]; Chlorella vulgaris extract has been described as a growth stimulant of lettuce [32]; or the aqueous extract of Haloxylon persicum shoots, which is a seed germination and seedling growth stimulant of wheat and black mustard weed [33]. However, the molecular reasons that could explain the activation of defensive mechanisms by plant extracts are poorly understood. In this study, four natural sources were used as plant-based preparations (PBPs) with the objective of protecting the Riñón bean variety against $\mathrm{Pph}$ in a sustainable way, evaluating some physiological parameters, crucial for the resistance/vulnerability of this bean, without detriment to yield.

Taking all of this into account, the aims of the present work were: (1) to screen the PBPs mentioned above by choosing those which showed major inhibition capacity against Pph growth; (2) to apply them on common bean leaves to evaluate their effect on redox state and yield, and (3) to evaluate whether they are able to activate defense mechanisms in common bean. For these purposes, the PBPs were tested by bioassays against Pph and once selected, applied on leaves of 1-month-old common bean Riñón plants. Finally, in vitro conditions were used to inoculate Pph in 21-day-old bean plants that had been pretreated or not with these PBPs, and the symptoms were evaluated. 


\section{Materials and Methods}

\subsection{PBP Sampling and Processing}

In the case of equisetum and nettle, they were collected from a field in León (Spain) during the spring season, when plants were in active vegetative growth. In the case of hop residue, it consisted of the remaining material after collecting the female flowers at the industrial drying stage from Villoria de Orbigo (León). With the grapevine residue, kindly donated by "Palomares" winery (Valdevimbre, León), we referred to the skin residue or pomace collected after the grapes were processed. Once this vegetable material was obtained, it was dried at $60{ }^{\circ} \mathrm{C}$ at least for one week until a constant weight was obtained. Then, the dried material was pulverized and stored at room temperature until use.

\subsection{Bioassays of PBPs against Pseudomonas syringae pv. phaseolicola}

Pseudomonas syringae van Hall 1902, CECT321 (Pph) was grown on liquid King's B (KB) medium for two days at $30{ }^{\circ} \mathrm{C}$ at $220 \mathrm{rpm}$. Plates for bioassays were prepared with different concentrations of PBPs: Urtica dioica (nettle, $U)$, grapevine pomace $\left(R_{G}\right)$, hop residue $\left(R_{H}\right)$ and Equisetum ssp (equisetum, E) at concentrations ranging between 0.4 and $10 \mathrm{mg} / \mathrm{mL}$, in Tryptic Soy Agar (TSA, BD Difco ${ }^{\mathrm{TM}}$, Waltham, MA, USA) following the manufacturer's indications, autoclaved at $121^{\circ} \mathrm{C}$ for $15 \mathrm{~min}$. When the medium was solid, a single well was made in the middle of the plate to place the bacteria, using $100 \mu \mathrm{L}$ of Pph dilution at a final concentration of $10^{8} \mathrm{CFU} / \mathrm{mL}$ in $0.9 \%(w / v) \mathrm{NaCl}$. The plates were incubated at $30{ }^{\circ} \mathrm{C}$ until bacteria growth and haloes areas were quantified using ImageJ software [34]). The $\mathrm{I}_{50}$ value for each PBP was calculated as the concentration of extract able to inhibit the Pph growth by $50 \%$.

\subsection{Experimental Design and PBP Application}

P. vulgaris variety Riñón (Protected Geographical Identification of Bean of La BañezaLeón) seeds were sterilized with $70 \%(v / v)$ ethanol $(30 \mathrm{~s})$ followed by $0.4 \%(w / v) \mathrm{NaClO}$ (20 $\mathrm{min})$. After being rinsed four times with sterile distilled water, the seeds were germinated in pots with a universal substrate (Blumenerde, Gramoflor, made in Germany) [6]. Leaves from common bean plants were sprayed with $2 \mathrm{~mL}$ per leaf of water (Mock), U, or $\mathrm{R}_{\mathrm{G}}$-PBPs at 21-, 24-, and 28-days post germination. All the PBPs were prepared at a final concentration of $1 \mathrm{mg} / \mathrm{mL}$. Seven days after the last application, the foliage leaves of 10 plants were collected and homogenized together with liquid nitrogen to form a pool for each condition. This experiment was repeated independently three times. The material was stored at $-80{ }^{\circ} \mathrm{C}$ until use. Plants were grown in a growth chamber at $25 \pm 2{ }^{\circ} \mathrm{C}$ with a $16 \mathrm{~h}$ photoperiod under a photon flux density of $45 \pm 5 \mu \mathrm{mol} \mathrm{m}^{-2} \mathrm{~s}^{-1}$ provided by daylight fluorescent tubes (TLD 36 W/830, Philips, Amsterdam, The Netherlands).

\section{4. $\mathrm{H}_{2} \mathrm{O}_{2}$ Content Measurement and Activity Assays of Antioxidant Enzymes}

Homogenized samples were suspended in extraction buffer (150 mg FW/mL): $0.05 \mathrm{M}$ Tris- $\mathrm{HCl}$ pH 7.5, $0.1 \mathrm{mM}$ EDTA, 0.1\% $(v / v)$ Triton X-100, 10\% $(v / v)$ glycerol and $2 \mathrm{mM}$ DTT and stored at $-80{ }^{\circ} \mathrm{C}$ until their use. For glutathione peroxidase (GPOX) activity (see below), a peroxidase buffer (0.04 M Tris- $\mathrm{HCl}$ pH 7.2, $1 \mathrm{mM}$ EDTA-2Na-2H and 5\% (v/v) glycerol) were used. For ascorbate peroxidase (APOX) activity, $20 \mathrm{mM}$ ascorbate was added to the extraction buffer. Then, samples were centrifuged at $15,000 \times g$ for 2 min [35]. For the measurements, the supernatants were used after estimating the protein content following the method described by Bradford [36].

Total $\mathrm{H}_{2} \mathrm{O}_{2}$ was estimated following the ferrous ammonium sulphate/xylenol orange (FOX) assay indication [37]. Each reaction contained $1 \mathrm{~mL}$ buffer $(1 \%(v / v)$ ethanol in $25 \mathrm{mM} \mathrm{H}_{2} \mathrm{SO}_{4}$ with $250 \mu \mathrm{M} \mathrm{FeSO}_{4}, 250 \mu \mathrm{M}\left(\mathrm{NH}_{4}\right)_{2} \mathrm{SO}_{4}, 100 \mu \mathrm{M}$ xylenol orange and $100 \mu \mathrm{M}$ sorbitol) and $150 \mu \mathrm{L}$ of sample. The absorbance was measured at $550 \mathrm{~nm}$ after 40 min of incubation and that value was used to obtain the $\mathrm{H}_{2} \mathrm{O}_{2}$ concentration on a calibration curve determined for each experiment due to the sensitivity of the method. 
Lipid peroxidation (lipid POX) was measured by the thiobarbituric acid reactive substances method using malondialdehyde (MDA) as reference [38].

Superoxide dismutase (SOD: EC 1.15.1.1) activity was measured following the SOD assay kit instructions (Sigma). Briefly, the SOD activity was measured as the inhibition of the formation of a colored compound which can be detected at $440 \mathrm{~nm}$, and its activity was determined from the inhibitory curve made with different concentrations of standards of a commercial SOD (from $0.001 \mathrm{U} / \mathrm{mL}$ to $2000 \mathrm{U} / \mathrm{mL}$ ). For this determination, $0.02 \mathrm{~mL}$ of either sample supernatant or standard was used.

Catalase (CAT: EC 1.11.1.6) activity was determined by Droillard's method [39], based on the absorbance decrease at $240 \mathrm{~nm}$ due to $\mathrm{H}_{2} \mathrm{O}_{2}$ reduction to water $\left(\varepsilon=39.58 \mathrm{M}^{-1} \mathrm{~cm}^{-1}\right)$. The reactions were measured during a period of $2 \mathrm{~min}$ at $25^{\circ} \mathrm{C}$ after adding $33 \mu \mathrm{L}$ of the extract to $1 \mathrm{~mL}$ of reaction buffer ( $50 \mathrm{mM}$ phosphate buffer, $\mathrm{pH} 7.0$ and $37.5 \mathrm{mM} \mathrm{H}_{2} \mathrm{O}_{2}$ ).

Ascorbate peroxidase (APOX: EC 1.11.1.11) activity was determined by the Hossain and Asada's method [40], based on the absorbance decrease at $290 \mathrm{~nm}$ due to ascorbate oxidation $\left(\varepsilon=2.8 \mathrm{mM}^{-1} \mathrm{~cm}^{-1}\right)$. The reaction was performed with a $900 \mu \mathrm{L}$ reaction buffer (50 mM HEPES-NaOH pH 7.6, $20 \mathrm{mM}$ ascorbate), $100 \mu \mathrm{L}$ of supernatant, and $10 \mu \mathrm{L}$ of $1.3 \mathrm{mM} \mathrm{H}_{2} \mathrm{O}_{2}$.

CIII peroxidase (GPOX: EC 1.11.1.7) activity was measured following the method described by Adam et al. (1995) [41], based on the increase in absorbance at $470 \mathrm{~nm}$ due to guaiacol oxidation $\left(\varepsilon=26.6 \mathrm{mM}^{-1} \mathrm{~cm}^{-1}\right)$. The reaction was performed with a $3 \mathrm{~mL}$ reaction buffer ( $100 \mathrm{mM}$ sodium acetate $\mathrm{pH} 5.5$ and $1 \mathrm{mM}$ guaiacol), $0.3 \mathrm{~mL}$ of $1.3 \mathrm{mM}$ $\mathrm{H}_{2} \mathrm{O}_{2}$, and $0.05 \mathrm{~mL}$ of supernatant.

\subsection{Gene Expression Analysis}

Homogenized samples (150 mg) were suspended in $1 \mathrm{~mL}$ of TriReagent (Invitrogen, Waltham, MA, USA, ref AM9738) to isolate the total RNA following the manufacturer's instructions without modifications. The total RNA $(5 \mu \mathrm{g})$ was reverse-transcribed using NG dART RT Kit $\left(\operatorname{Eur}_{\mathrm{x}}\right)$ according to the manufacturer's instructions and using an amplification cycle of $10 \mathrm{~min}$ at $25^{\circ} \mathrm{C}, 60 \mathrm{~min}$ at $40{ }^{\circ} \mathrm{C}$, and $10 \mathrm{~min}$ at $85^{\circ} \mathrm{C}$ in a T-Gradient Thermal Cycler (Applied Biosystems, Waltham, MA, USA).

The cDNA obtained was used as a template for quantitative Real-Time Polymerase Chain Reaction (qRT-PCR) assays, using PowerUp SYBR Green PCR Master Mix kit (ThermoFisher, Waltham, MA, USA) and StepOnePlus ${ }^{\mathrm{TM}}$ Real-Time System (Applied Biosystems). Each reaction contained $10 \mu \mathrm{L}$ of $2 \times$ Master Mix, $0.3-0.8 \mu \mathrm{M}$ primers, and $50 \mathrm{ng}$ cDNA, performing each one in triplicate. The primers used in this study are shown in Table 1 . The primer concentration was optimized by testing different concentrations and the $\mathrm{qPCR}$ efficiency was determined by the equation $\mathrm{E}=\left(10^{-1 / \text { slope }}-1\right) \times 100$. The reference gene used in this study was Ukn1 [42], and all data were analyzed by the $2^{-\Delta \Delta \mathrm{Ct}}$ method [43].

Table 1. Primers used in this work for qRT-PCR analyses, with the sequence, amplicon length, primer efficiency, annealing temperature, functional annotation, and reference or NCBI accession.

\begin{tabular}{|c|c|c|c|c|c|c|}
\hline $\begin{array}{l}\text { Gene } \\
\text { Name }\end{array}$ & Sequence $\left(5^{\prime}-3^{\prime}\right) \mathrm{Fw} / \mathrm{Rev}$ & $\begin{array}{l}\text { Amplicon } \\
\text { Length }\end{array}$ & $\begin{array}{l}\text { Primer } \\
\text { Efficiency }\end{array}$ & $\begin{array}{l}\text { Annealing } \\
\text { Temperature }\end{array}$ & $\begin{array}{l}\text { Functional } \\
\text { Annotation }\end{array}$ & $\begin{array}{c}\text { Reference } \\
\text { or NCBI } \\
\text { Accesion }\end{array}$ \\
\hline Ukn1 & $\begin{array}{l}\text { ATTCCCATCATGCAGCAAAG/ } \\
\text { AGATCCСTCCAGGTCAATCC }\end{array}$ & $192 \mathrm{bp}$ & $97.3 \%$ & $62.1^{\circ} \mathrm{C}$ & Unknown & [42] \\
\hline PR1 & $\begin{array}{c}\text { TGGTCCTAACGGAGGATCAC/ } \\
\text { TGGCTTTTCCAGCTTTGAGT }\end{array}$ & $170 \mathrm{bp}$ & $94.0 \%$ & $63.4^{\circ} \mathrm{C}$ & $\begin{array}{l}\text { Pathogenesis } \\
\text { related } 1\end{array}$ & {$[44]$} \\
\hline$M A P K K$ & $\begin{array}{l}\text { TTCTACATGGGCAGGTTTCC / } \\
\text { GGGAGATGAAATCCCTGAAG }\end{array}$ & $132 \mathrm{bp}$ & $92.3 \%$ & $60.6^{\circ} \mathrm{C}$ & $\begin{array}{c}\text { Mitogen } \\
\text { activated } \\
\text { protein kinase } \\
\text { kinase }\end{array}$ & {$[45]$} \\
\hline
\end{tabular}


Table 1. Cont.

\begin{tabular}{|c|c|c|c|c|c|c|}
\hline $\begin{array}{l}\text { Gene } \\
\text { Name }\end{array}$ & Sequence $\left(5^{\prime}-3^{\prime}\right) \mathrm{Fw} / \mathrm{Rev}$ & $\begin{array}{l}\text { Amplicon } \\
\text { Length }\end{array}$ & $\begin{array}{l}\text { Primer } \\
\text { Efficiency }\end{array}$ & $\begin{array}{l}\text { Annealing } \\
\text { Temperature }\end{array}$ & $\begin{array}{l}\text { Functional } \\
\text { Annotation }\end{array}$ & $\begin{array}{c}\text { Reference } \\
\text { or NCBI } \\
\text { Accesion }\end{array}$ \\
\hline WRKY33 & $\begin{array}{c}\text { TTTCACAGGACAGGTTCCAGC/ } \\
\text { CCTTTGACAGAAATGACTGAAGGA }\end{array}$ & $161 \mathrm{bp}$ & $93.8 \%$ & $63.8^{\circ} \mathrm{C}$ & $\begin{array}{c}\text { WRKY } \\
\text { transcription } \\
\text { factor }\end{array}$ & [45] \\
\hline RIN4 & $\begin{array}{l}\text { GTTCAGTGTTGCTGCTTTGC/ } \\
\text { CACACACCTCATGACCATACAC }\end{array}$ & $117 \mathrm{bp}$ & $92.2 \%$ & $63.6^{\circ} \mathrm{C}$ & $\begin{array}{c}\text { RPM1 } \\
\text { interacting } \\
\text { protein } 4\end{array}$ & [6] \\
\hline PAL1 & $\begin{array}{l}\text { TGAGAGAGGAGTTGGGCACT } \\
\text { TTCCACTCTCCAAGGCATTC }\end{array}$ & $135 \mathrm{bp}$ & $99.4 \%$ & $62.9^{\circ} \mathrm{C}$ & $\begin{array}{l}\text { Phenylalanine } \\
\text { ammonia-lyase }\end{array}$ & [45] \\
\hline
\end{tabular}

\subsection{Yield Assessment}

In this case, common bean plants were grown and treated as indicated above in the experimental design (Figure 1). After the seeds were sterilized, they were germinated in pots with a universal substrate (Blumenerde, Gramoflor, made in Germany). At 21-, 24-, and 28-days post germination, the plants were sprayed on foliage leaves with $2 \mathrm{~mL}$ per leaf of sterile water (Mock) or PBPs at a concentration of $1 \mathrm{mg} / \mathrm{mL}$. Bean plants were established until they developed completely after 3 months (reproductive stage R8). Then, the photosynthetic parameters (chlorophyll concentration, maximum and effective quantum yield) and the related productivity were measured: (i) per plant (number of pods, number of seeds, and weight of these seeds, referred to as yield) and (ii) per pod (length, weight, and number of seeds).

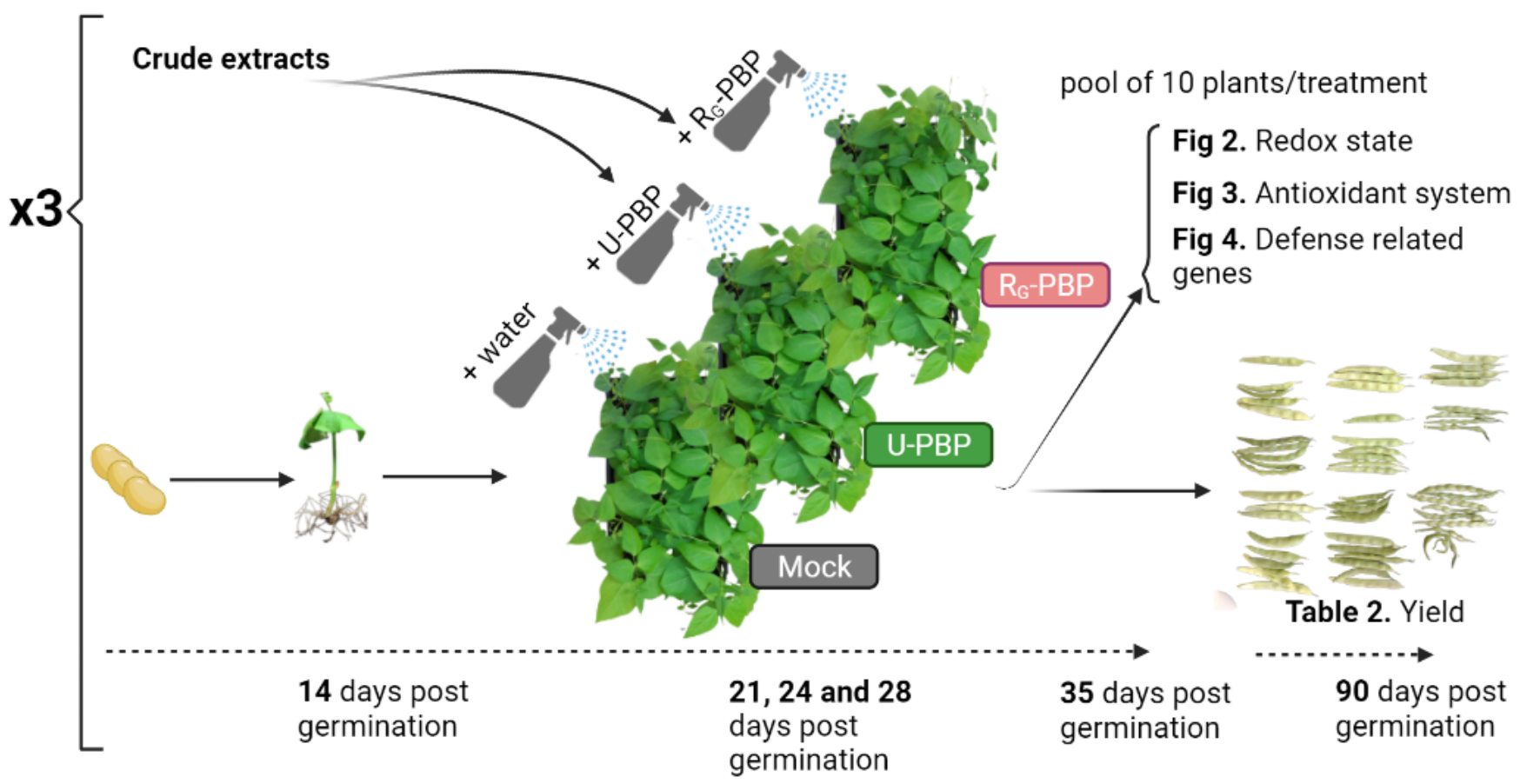

Figure 1. Experimental design. Seeds of common bean P. vulgaris L. cultivar Riñón were grown ex vitro. Leaves from common bean plants were sprayed with water (Mock), Urtica dioica (U), or grapevine pomace $\left(\mathrm{R}_{\mathrm{G}}\right)$ plant-based preparations (PBPs) at 21-, 24-, and 28-days post germination. All plants were grown for 7 days more and then the foliage leaves for each treatment (pool of 10 plants per treatment) were collected to be homogenized with liquid nitrogen and stored at $-80^{\circ} \mathrm{C}$. The experiment was repeated three independent times $(n=3)$. In these samples, the redox state (total 
hydrogen peroxide and lipid peroxidation), antioxidant activities, and the expression of defenserelated genes were analyzed. In the case of yield examination, the procedure was followed as mentioned above but plants were grown until R8 developmental stage, 90 days post germination, when pods were completely formed. Created with Biorender.com.

\subsection{Infection Assays}

After being rinsed four times with sterile distilled water, the seeds were germinated under in vitro conditions using glass jars ( $946 \mathrm{~mL}$ of volume) with a universal substrate (Blumenerde, Gramoflor, made in Germany). All steps were carried out under sterile conditions. Plants were grown in a growth chamber at $25 \pm 2{ }^{\circ} \mathrm{C}$ with a $16 \mathrm{~h}$ photoperiod under a photon flux density of $45 \pm 5 \mu \mathrm{mol} \mathrm{m} \mathrm{m}^{-2} \mathrm{~s}^{-1}$ provided by daylight fluorescent tubes (TLD $36 \mathrm{~W} / 830$, Philips) until the end of the experiment. The plants at the V1 stage were sprayed on foliage leaves with $2 \mathrm{~mL}$ per leaf of sterilized water (Mock condition) or $1 \mathrm{mg} / \mathrm{mL} \mathrm{U}$ or $\mathrm{R}_{\mathrm{G}}$ - PBPs. After 7 days, some plants previously treated with PBPs or not were sprayed with $2 \mathrm{~mL}$ of Pph solution on foliage leaves. The plants were grown for 7 days more to observe the phenotype and analyze general physiological parameters such as fresh weight and length of the aerial part (Figure 2).

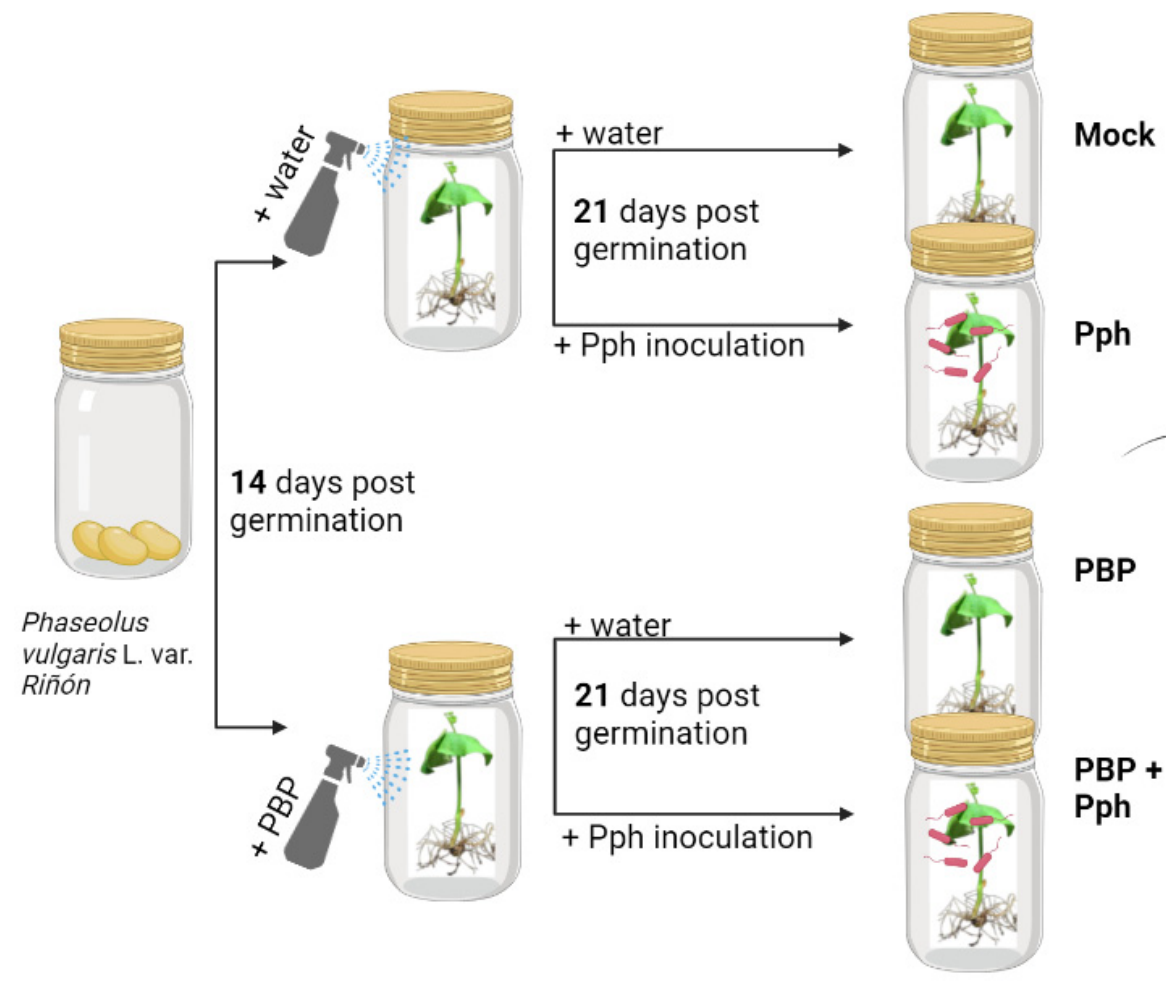

Fig. 5 Disease phenotyping

Fig. 6 Length and weight

Figure 2. Experimental design for in vitro infections. Seeds of common bean P. vulgaris L. cultivar Riñón were grown in vitro. Leaves from common bean plants at V1 stage were sprayed with $1 \mathrm{mg} / \mathrm{mL}$ of plant-based products (PBPs) of Urtica dioica (U) or grapevine pomace $\left(\mathrm{R}_{\mathrm{G}}\right)$ per leaf or with sterilized water (Mock condition). After 7 days, some plants previously treated or not with PBPs were sprayed with $2 \mathrm{~mL}$ of the Pseudomonas syringae pv. phaseolicola (Pph) solution on foliage leaves, resulting in $\mathrm{U}+\mathrm{Pph}, \mathrm{R}_{\mathrm{G}}+\mathrm{Pph}$, and Mock + Pph treatments. All plants were grown for 7 days more prior to phenotyping and measurement of length and weight.

\subsection{Statistical Analysis and Data Representation}

All results were expressed as the means \pm standard error (SE) of three independent experiments and were statistically analyzed by SPSS software (IBM SPSS Statistics for Windows, Version 25.0, 2017). Data normality was checked firstly by Kolmogorov-Smirnov test and then the data were analyzed by one-way ANOVA with a Tukey post hoc test 
to evaluate the differences between treatments. The results were significantly different considering $p<0.05$. Only the parameters pod/plant, yield, and length/pod did not follow normality and, therefore, the Kruskal-Wallis test was used in these cases (with a significance of $p<0.05$ ). The results were represented using GraphPad Prism 6, GraphPad Software, La Jolla, CA, USA (www.graphpad.com, accessed date 15 July 2021).

\section{Results}

\subsection{Screening of PBPs against Halo Blight Disease}

Due to their previous potential activity and the fact that they have no other economic interest, four different plant-based preparations (PBPs) were tried: grapevine pomace $\left(\mathrm{R}_{\mathrm{G}}\right)$, hop residue $\left(\mathrm{R}_{\mathrm{H}}\right)$, nettle (Urtica dioica, $\mathrm{U}$ ), and equisetum (Equisetum ssp, E). The potential of these PBPs to inhibit Pph growth was evaluated by bioassays with a concentration range between 0.4 and $10 \mathrm{mg} / \mathrm{mL}$. The percentage of bacterial growth with respect to the control was represented in Figure 3. As a result, Pph growth diminished as the concentration of PBPs was higher. However, a higher decrease was observed for $\mathrm{R}_{\mathrm{G}}$ and U-PBPs, as the concentration of PBPs needed to inhibit Pph growth to a $50 \%\left(\mathrm{I}_{50}\right)$ was 0.7 and $1.0 \mathrm{mg} / \mathrm{mL}$, respectively. This result indicated that $R_{G}$ and U-PBPs were more effective in inhibiting bacterial growth than $\mathrm{E}$ and $\mathrm{R}_{\mathrm{H}}-\mathrm{PBPs}$, which showed a respective $\mathrm{I}_{50}$ value of 5.9 and $6.1 \mathrm{mg} / \mathrm{mL}$. Finally, the inhibition for all PBPs assayed was similar at concentrations higher than $5 \mathrm{mg} / \mathrm{mL}$.
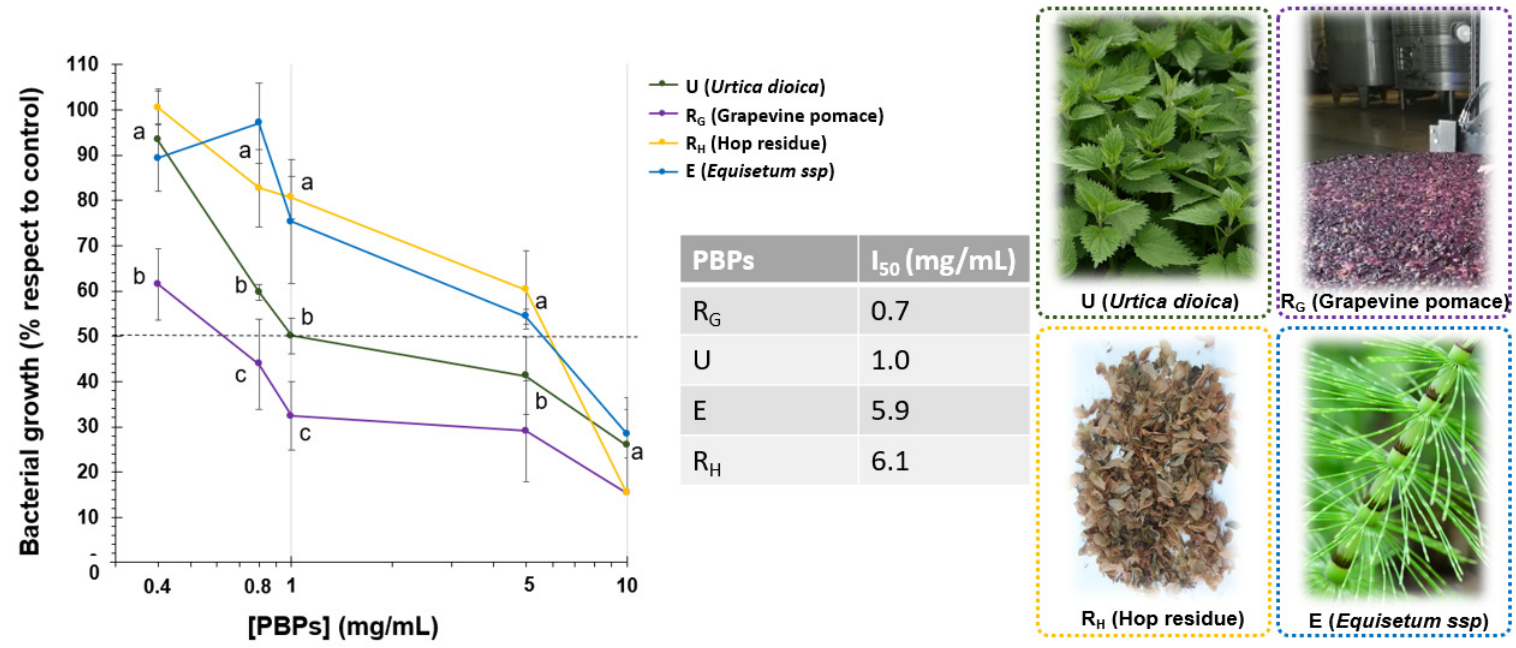

Figure 3. Growth inhibition of Pseudomonas syringae pv. phaseolicola (Pph) in the presence of different concentrations $(0.4,0.8,1,5$, and $10 \mathrm{mg} / \mathrm{mL})$ of grapevine pomace $\left(R_{G}\right)$, hop residue $\left(R_{H}\right)$, nettle (Urtica dioica, $\mathrm{U}$ ) and equisetum (Equisetum ssp, E). Data shown are the mean $\pm \mathrm{SE}$ of three independent experiments. The respective concentrations of each extract, for which the bacterial growth was inhibited to $50 \%\left(\mathrm{I}_{50}\right)$, were estimated and summarized in the table. Statistically significant differences were analyzed by means of one-way ANOVA with a Tukey post hoc test $(p<0.05)$. Pictures of the plant extract before harvesting are shown.

\subsection{Effect of the Application of Nettle and Graperine Pomace PBPs on the Physiological Redox} State of Common Bean

A first experiment was performed in common bean to evaluate a possible toxic effect of PBP application. The $\mathrm{R}_{\mathrm{G}}$ and U-PBPs were selected according to their major Pph-growth inhibition capacity. After treatments, different antioxidant activities were checked to study possible oxidative damage on leaves. As shown in Figure 4, the $\mathrm{H}_{2} \mathrm{O}_{2}$ content and lipid peroxidation were analyzed first. The application of $\mathrm{R}_{\mathrm{G}}$ and U-PBPs reduced the total $\mathrm{H}_{2} \mathrm{O}_{2}$ content by $50 \%$ compared to Mock (Figure $4 \mathrm{~A}$ ). However, due to the action of ROS, the lipid peroxidation increased after both treatments (Figure 4B) suggesting the participation of other ROS. To deepen the knowledge of the antioxidant system, some antioxidant enzyme activities were also evaluated. Although the total $\mathrm{H}_{2} \mathrm{O}_{2}$ content 
decreased after $\mathrm{R}_{\mathrm{G}}$ and U-PBPs application, the activity of the SOD enzyme, which produces $\mathrm{H}_{2} \mathrm{O}_{2}$ (Sharma et al., 2012), increased (Figure 4C). However, the CAT activity, which uses $\mathrm{H}_{2} \mathrm{O}_{2}$ as a substrate [46,47], was reduced after both treatments (Figure 4D). On the other hand, the activities of APOX and GPOX, which also use $\mathrm{H}_{2} \mathrm{O}_{2}$ as a substrate, did not change compared to Mock (Figure 4E,F).
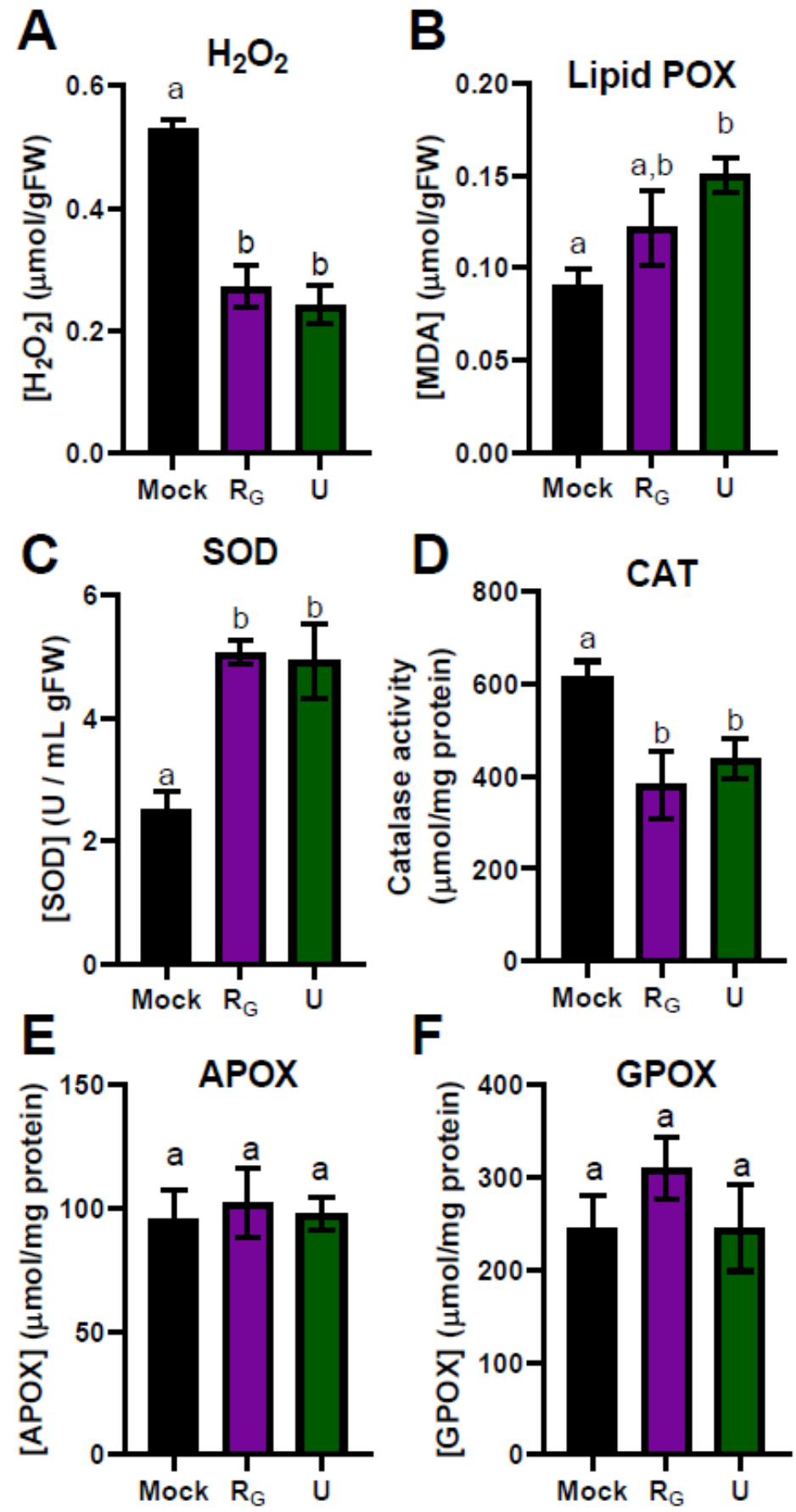

Figure 4. Total $\mathrm{H}_{2} \mathrm{O}_{2}$ (A); lipid peroxidation measured as malonaldehyde (MDA) production (B); superoxide dismutase (SOD) (C); catalase (CAT) (D); ascorbate peroxidase (APOX) (E); guaiacol peroxidase (GPOX) (F), of non-treated (Mock, black bars) and treated common bean with grapevine pomace $\left(R_{G}\right.$, purple bars) and nettle (U, green bars). Data shown are the mean \pm SE of three independent experiments. Statistically significant differences were analyzed by means of one-way ANOVA with a Tukey post hoc test $(p<0.05)$. 


\subsection{U-PBP Increased Expression of Some Defense-Related Genes}

A qPCR experiment was performed to evaluate the level of expression of some representative genes at different levels of the defense state, which were chosen as they had been previously reported to be involved in defense in several studies in common bean $[6,45]$ and also, during elicitation processes with chemical compounds such as $\beta$-aminobutyric acid (BABA) and 2,6-dichloroisonicotinic acid (INA) [7]. When common bean plants were treated with U-PBP, the expression of all defense genes increased significantly with respect to Mock and $\mathrm{R}_{\mathrm{G}}-\mathrm{PBP}$ (Figure 5). The highest upregulation was observed in PR1. In fact, PR1 is a family of proteins, whose expressions are increased considerably when the immune system is activated [48].

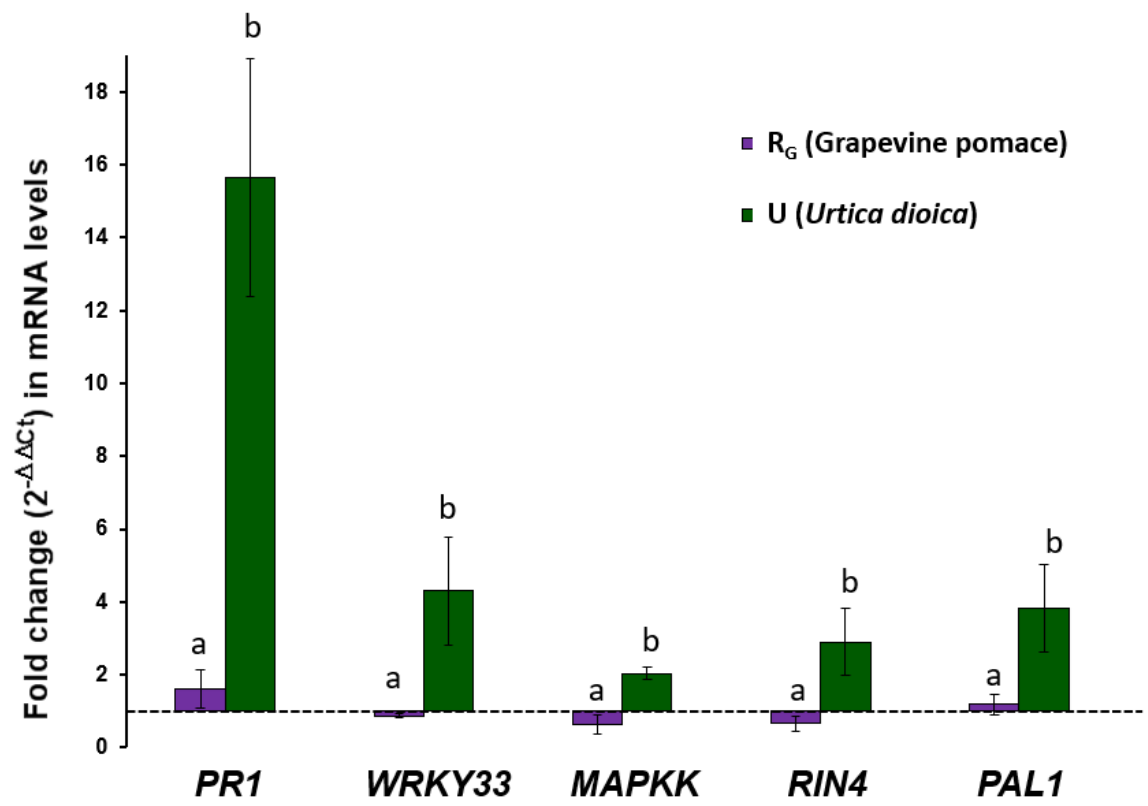

Figure 5. Analysis of relative expression levels with respect to Mock (dash line) of common bean defense-related genes (PR1, WRKY33, MAPKK, RIN4, and PAL1) after grapevine pomace $\left(\mathrm{R}_{\mathrm{G}}\right.$, purple bars) and nettle (U, green bars) application. Data shown are the mean $\pm \mathrm{SE}$ of three independent experiments. Statistically significant differences were analyzed by means of one-way ANOVA with a Tukey post hoc test $(p<0.05)$.

\subsection{Yield Did Not Vary after Treatments}

Once the redox status and immunity activation were analyzed, physiological parameters were analyzed in order to reveal whether the agronomic production was affected by PBP application. With that purpose, the experiment was replicated but plants were allowed to grow in this case until they developed true pods and seeds. The variables measured were photosynthesis related (chlorophyll concentration, maximum and effective quantum yield) and productivity related. Specifically, the number of pods, the number of seeds, and the weight of these seeds (referred to as yield) were measured per plant. In addition, the length, weight, and the number of seeds were checked for each pod. The results are summarized in Table 2. Interestingly, no significant differences were observed after treatments, compared to Mock, indicating that the application of PBPs did not imply losses in productivity. The U-PBP treatment even increased the number of pods, although this did not result in a higher seed weight, whereas $R_{G}-P B P$ increased the $n^{\circ}$ of seeds per pod and per plant but not the pod weight, which means that seeds were smaller than in Mock. On the other hand, both treatments slightly increased the chlorophyll content compared to Mock without affecting the photosynthetic parameters analyzed. 


\subsection{Common Bean Showed Less Symptoms of Halo Blight Disease after Application of U-PBP}

As both $\mathrm{R}_{\mathrm{G}}$ and U-PBPs showed a powerful inhibitory effect on Pph growth, and U-PBP caused an increase in expression levels of the defense-related genes analyzed, we wanted to study whether these PBPs protected bean plants against Pph. To confirm this, bean plants were grown in vitro and treated with $\mathrm{R}_{\mathrm{G}}$ and U-PBPs, and the phenotypic symptoms produced by halo blight disease were analyzed after the Pph inoculation. As shown in Figure 6, compared to Mock, the Pph inoculation produced the appearance of lesions on leaves, typical symptoms of the disease [2]. PBPs application did not produce any visible stresses compared to Mock. However, once inoculated with Pph, foliar damage was reduced considerably when the plants were previously treated with U-PBP. However, the pre-treatment with $\mathrm{R}_{\mathrm{G}}-\mathrm{PBP}$ did not prevent the appearance of foliar damage to the same extent as with U-PBP.

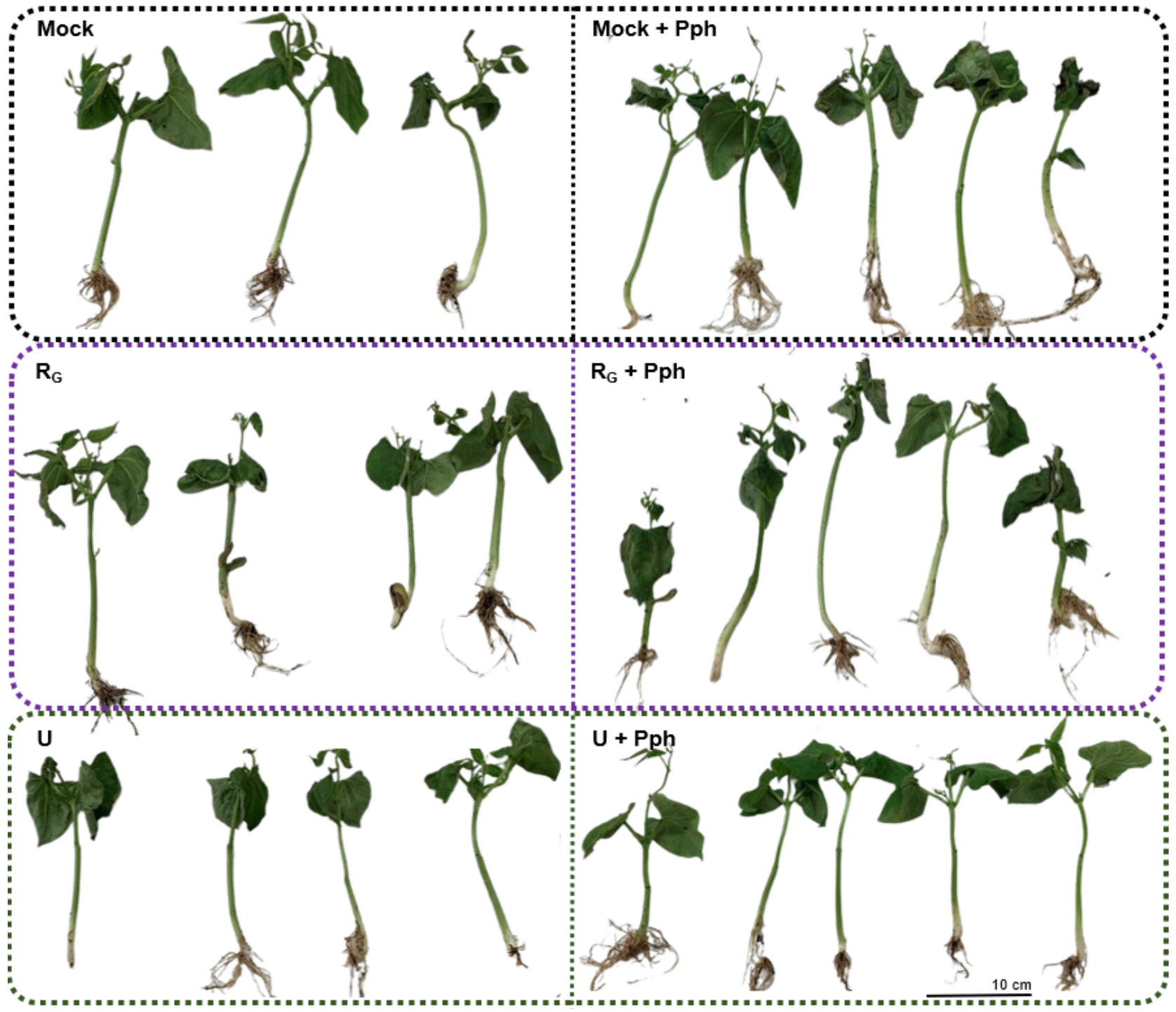

Figure 6. Phenotypic damage caused by the virulent $P$. syringae pv. phaseolicola (Pph) in common bean plants. Entire plants are shown to compare symptoms in Mock; after the Pph inoculation $($ Mock $+P p h)$; in plants pre-treated with grapevine pomace $\left(R_{G}-P B P\right)$, with $\left(R_{G}+P p h\right)$ or without $\left(\mathrm{R}_{\mathrm{G}}\right)$ Pph inoculation; and plants pre-treated with Urtica dioica (U-PBP), with (U + Pph) or without (U) Pph inoculation. Pictures correspond to one experiment representative of three independent ones with similar results. 
In addition, the lengths (Figure 7A) and fresh weights of the entire plants (Figure 7B) were measured. According to the symptoms observed (Figure 6), the length and fresh weight decreased significantly after all the treatments, especially after the Pph inoculation. However, although the U pre-treatment had involved a decrease in fresh weight compared to Mock, the posterior Pph inoculation did not affect this parameter significantly.

Table 2. Yield and photosynthetic parameters measured in common bean after treatments with $U$ and $\mathrm{R}_{\mathrm{G}}$-PBPs. Data shown are the mean $\pm \mathrm{SE}(n=12)$. Statistically significant differences were analyzed according to one-way ANOVA $(p<0.05)$ when normality or to Kruskal-Wallis test when not.

\begin{tabular}{ccccccc}
\hline & \multicolumn{2}{c}{ Mock } & & & & U \\
\hline Pods/Plant & 3.889 & $\pm 0.964 \mathrm{~ns}$ & 4.467 & $\pm 0.576 \mathrm{~ns}$ & 3.154 & $\pm 0.470 \mathrm{~ns}$ \\
\hline Yield (g/Plant) & 3.481 & $\pm 1.273 \mathrm{~ns}$ & 3.473 & $\pm 0.874 \mathrm{~ns}$ & 3.360 & $\pm 0.658 \mathrm{~ns}$ \\
\hline $\mathrm{n}^{\text {o seeds/Plant }}$ & 11.333 & $\pm 3.167 \mathrm{~ns}$ & 11.800 & $\pm 1.598 \mathrm{~ns}$ & 12.615 & $\pm 2.407 \mathrm{~ns}$ \\
\hline Pod length $(\mathrm{cm})$ & 12.470 & $\pm 0.440 \mathrm{~ns}$ & 12.520 & $\pm 0.300 \mathrm{~ns}$ & 11.810 & $\pm 0.430 \mathrm{~ns}$ \\
\hline Pod weight $(\mathrm{g})$ & 4.352 & $\pm 0.646 \mathrm{~ns}$ & 5.662 & $\pm 0.423 \mathrm{~ns}$ & 4.536 & $\pm 0.446 \mathrm{~ns}$ \\
\hline $\mathrm{n}^{\text {o seeds/Pod }}$ & 3.110 & $\pm 0.390 \mathrm{~ns}$ & 2.900 & $\pm 0.280 \mathrm{~ns}$ & 3.620 & $\pm 0.360 \mathrm{~ns}$ \\
\hline Chlorophyll $(\mu \mathrm{g} / \mathrm{mL} / \mathrm{g}$ FW) & 206.564 & $\pm 28.337 \mathrm{~ns}$ & 224.632 & $\pm 22.415 \mathrm{~ns}$ & 218.675 & $\pm 18.057 \mathrm{~ns}$ \\
\hline Maximum Quantum Yield & 0.803 & $\pm 0.015 \mathrm{~ns}$ & 0.801 & $\pm 0.008 \mathrm{~ns}$ & 0.806 & $\pm 0.016 \mathrm{~ns}$ \\
\hline Effective Quantum Yield & 0.526 & $\pm 0.037 \mathrm{~ns}$ & 0.490 & $\pm 0.031 \mathrm{~ns}$ & 0.541 & $\pm 0.027 \mathrm{~ns}$ \\
\hline
\end{tabular}

A

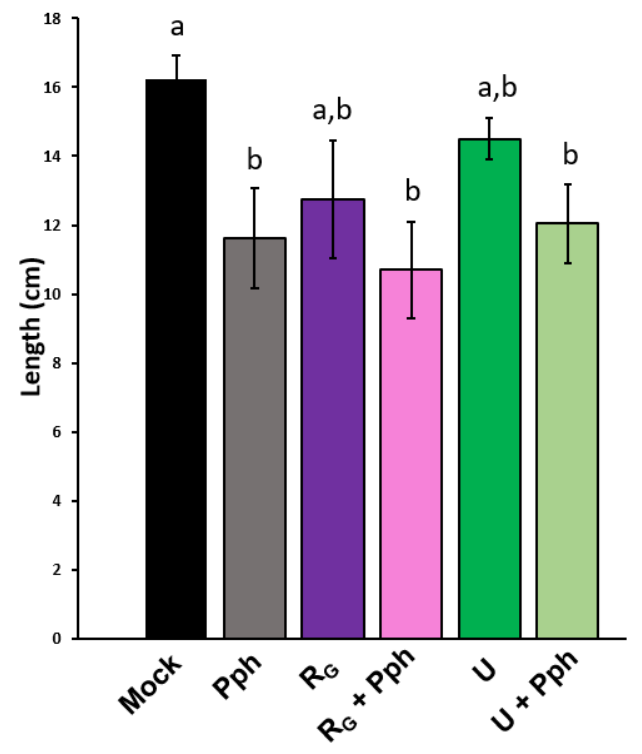

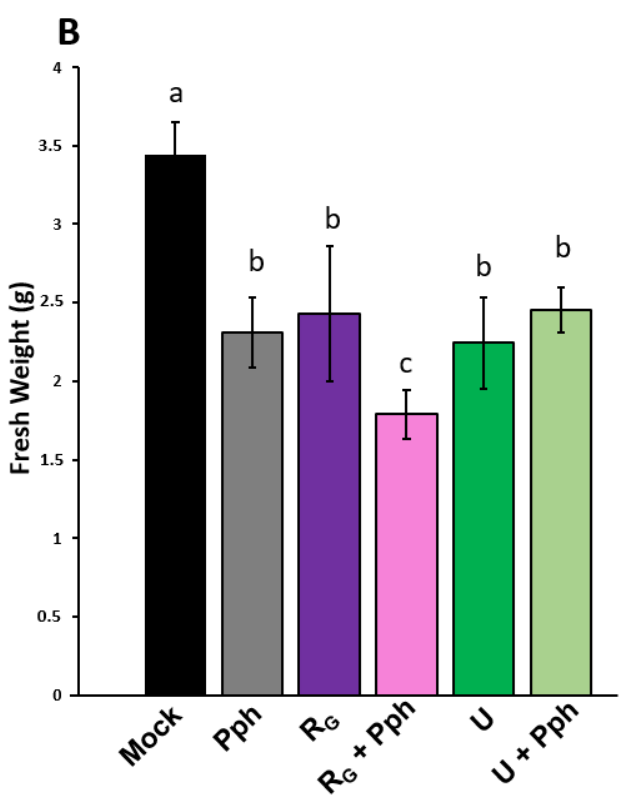

Figure 7. Length (A) and fresh weight (B) of non-treated (Mock; black bars) and pre-treated common bean with grapevine pomace $\left(\mathrm{R}_{\mathrm{G}}\right.$; purple bars) and nettle (U; green bars), and their respective PBPtreated plants inoculated with Pph $\left(\mathrm{R}_{\mathrm{G}}+\right.$ Pph; $\mathrm{U}+$ Pph; bars in corresponding soft colors). Data shown are the mean $\pm \mathrm{SE}$ of three independent experiments. Statistically significant differences were achieved according to one-way ANOVA $(p<0.05)$, post hoc Tukey test.

\section{Discussion}

Plant diseases produced by bacterial infections are responsible for severe losses in crop production worldwide. In the case of common bean, halo blight infection results firstly in critical economic problems for farmers and in difficulties for breeding in certain areas where this legume is the only protein support. However, it is necessary to search for new agronomic techniques or protocols that avoid disease in common bean or at least, diminish symptoms and losses, as the current phytosanitary treatments are not completely effective. 
In this study, we tested the capacity of some plant-based preparations (PBPs) to inhibit Pph growth. Their selection was thought in terms of circular economy, as they are residues from other manufacturing processes such as grapevine pomace $\left(\mathrm{R}_{\mathrm{G}}\right)$ and hop residues $\left(\mathrm{H}_{\mathrm{R}}\right)$, or wild species without another industry or agronomic use such as equisetum (E) or nettle (U). The results showed an inhibitory potential of all PBPs in a concentration-dependent manner (Figure 3). $\mathrm{R}_{\mathrm{H}}$-PBP was obtained from female hop cones which accumulate a great amount of secondary metabolites such as xanthohumol and other derivatives, with strong antimicrobial activity against anaerobic or ruminal bacteria $[49,50]$. In this line, equisetum (E-PBP in this study) has shown antibiotic activity against some Gram-positive bacteria and oomycetes [51,52]. However, the most effective ones were $\mathrm{R}_{\mathrm{G}}$ and U-PBPs, with an $\mathrm{I}_{50}$ of 0.7 and $1.0 \mathrm{mg} / \mathrm{mL}$, respectively. In the case of nettle, it has been shown to be richer in individual polyphenols than other wild plants [53]. Due to its variety of phytochemicals, this species has shown antimicrobial activity against Gram-positive and Gram-negative bacteria, including Pseudomonas aeruginosa and Pseudomonas syringae pv. tomato [54]. In the case of grapevine, different parts of Vitis vinifera, such as stems, skins, and seeds are rich sources of polyphenols, hydroxybenzoic, and hydroxycinnamic acids, flavonols, stilbenes, procyanidins, or anthocyanins [55]. This consolidates the observations of some studies which have shown the antibiotic potential of grapevine agro-industrial wastes against Staphylococcus aureus, Escherichia coli, and Pseudomonas aeruginosa [56], Candida strains [57], or biofilm formation of some Gram-positive cocci [58].

As mentioned above, there were several studies that demonstrated the antimicrobial effect of these preparations against other bacteria, but there was no knowledge about their potential against Pph in common bean. For this reason, we wanted to evaluate whether $\mathrm{R}_{\mathrm{G}}$ and U-PBPs, as the most effective to inhibit Pph growth, could be applied in common bean as antimicrobials and also as defense elicitors. The first step was to study a possible detrimental effect after the application of the PBPs. The metabolism related to ROS is tightly regulated and participates in controlling different stress processes [59], being the content of $\mathrm{H}_{2} \mathrm{O}_{2}$ one of the most affected during biotic attacks. After $\mathrm{R}_{\mathrm{G}}$ and U-PBP application, total $\mathrm{H}_{2} \mathrm{O}_{2}$ decreased (Figure 4A) while lipid peroxidation increased (Figure 4B) one week after the first treatment, which could have been enough time to buffer any stress and could have been materialized in a higher lipid POX level as a footprint (Figure 4B).

The SOD activation (Figure $4 \mathrm{C}$ ) should involve the production of more $\mathrm{H}_{2} \mathrm{O}_{2}$, which we did not detect because it could be used together with superoxide ion ${ }^{*} \mathrm{O}$ to form ${ }^{*} \mathrm{OH}$, which is responsible for lipid POX $[60,61]$. This lack of an intense $\mathrm{H}_{2} \mathrm{O}_{2}$ burst would explain why neither CAT (Figure 4D) nor POX were activated. Another explanation could be that the $\mathrm{H}_{2} \mathrm{O}_{2}$ produced after applying the PBPs was mobilized in the signaling process, as it was reduced up to $50 \%$ compared to Mock (Figure $4 \mathrm{~A}$ ). At the molecular level, one of the roles of ROS is to react with a broad range of metabolites. Therefore, ROS could be consumed by the ROS-scavenging machinery and result in ROS-sensing mechanisms [59,62], such as the oxidative posttranslational modifications of methionine residues. In this sense, $R_{G}$ is a resveratrol-rich PBP which is a well-known ROS-scavenger molecule and lipid peroxidation protector [63], which could explain the lack of Lipid POX difference (Figure 4B).

As previously suggested, the Riñon variety is susceptible to be elicited with the synthetic compound INA [9]. To analyze the capacity of the PBPs application in the activation of the immune system, the expression of some defense-related genes such as WRKY33, MAPKK, RIN4, PR1, and PAL1 were evaluated (Figure 5). This gene expression analysis demonstrated that plants treated with U-PBP showed upregulation of all the studied genes (Figure 5). This is the case of WRKY33 (WRKY transcription factor), involved in the balance between necrotrophic and biotrophic responses [64], and MAPKK (mitogen-activated protein kinase kinase), which indicates that the first steps in defense were activated [65]. This was in line with the activation of RIN4 (RPM1-interacting protein), which recognizes various bacterial effectors [65]. The ability of U-PBP to trigger common bean defense response was demonstrated most of all by the higher expression of PR1 (pathogenesis-related 1), as it is one of the most abundantly produced proteins upon pathogen attack [66] and a key 
regulator of defense [67]. Although its exact function remains unknown, PR1 could have antimicrobial activity or regulate salicylic acid-mediated response [68]. Interestingly, the fold change was higher than in previous studies with this common bean Riñon variety after Pph infection, which suggested here a reason for the susceptibility of this plant against the pathogen [6]. The fact that also PAL1 (phenylalanine and histidine ammonia-lyase) and the other genes analyzed showed upregulation compared to Mock would suggest that the immune activation happened at all levels, and consequently, a systemic acquired response would have been activated $[45,69]$. However, $\mathrm{R}_{\mathrm{G}}-\mathrm{PBP}$ application did not produce changes in the expression of genes evaluated in this work, which could indicate that this PBP has antimicrobial and antioxidant effects but not elicitor effect.

The activation of immunity in common bean after the treatment with the U-PBP was tested by inoculating plants in vitro with Pph. As shown in Figure 6, the damage was restricted to foliar margins when inoculation took place after U-PBP pre-treatment. By contrast, the Pph inoculation in Mock produced the appearance of lesions on leaves, with the disintegration of tissues. In accordance with this observation, common bean plants elicited with BABA or INA show lesser leaf damage after the Pph inoculation than control plants [7], indicating that chemical elicitation reduces the disease effects in a similar way as PBP elicitation. In addition, the U-PBP pre-treatment did not significantly produce a reduction in plant length (Figure $7 \mathrm{~A}$ ), but caused a decrease in fresh weight, compared to Mock (Figure 7B). However, the $\mathrm{U}+$ Pph treatment did not affect fresh weight compared to the U-PBP application (Figure 6).

As previously described, the defense activation usually negatively impacts plant growth, as resources are limited for a plant and that pool of energy reserves must be divided into growth or defense, which has an agricultural impact [70,71]. This reduction in fitness remains partially unknown, but one explanation could lie in the high amount of energy employed in activating processes that would be unnecessary to combat all stresses [70]. This is the case of treatments with the commercial benzothiadiazole, a synthetic SA-analog used to enhance resistance by inducing systemic acquired resistance in crops [11,72]. In the absence of pathogens, its application in wheat produced a decrease in yield [12], but the loss on yield was buffered when wheat suffered from powdery mildew [11]. However, in this work, yield parameters such as yield, $n^{\circ}$ of seeds per plant, or length and weight of the pods as well as photosynthetic parameters were not affected by application of any of the PBPs selected (Table 2). Only in the case of U-PBP application was there a slight tendency to decrease the number of seeds per pod offset by a slight tendency to increase the number of pods per plant, indicating that this PBP could be applied on the field without an important detrimental effect. In line with this, Urtica extract application in common bean produced an increase in leaf area, stem height, and diameter, while the weight of pods was similar to the control, suggesting that the yield was not affected by Urtica treatment [73] and thus, the extract would have a buffer effect against the negative effects of Pph (Figure 6).

\section{Conclusions}

To summarize, in this study, we proved four plant-based preparations to be used in common bean against the pathogen by studying their inhibitory effect on Pph growth. The two most effective PBPs $\left(R_{G}\right.$ and $U$ ) were applied in common bean to evaluate whether they were detrimental to the plant. After observing that the U-PBP application involved a signaling redox process, the expression levels of some defense-related genes were analyzed, which showed upregulation of all of them, mainly in PR1. First, in vitro trials suggested that the U-PBP application involved the protection of common bean against Pph. The elicitation of bean defense with U-PBP involved a decrease in some yield parameters, but it did not affect the final production. All these findings suggest that Urtica dioica plant-based preparations could be used in the near future to diminish halo blight disease effects. 


\begin{abstract}
Author Contributions: Conceptualization, A.G.D.1.R. and P.G.-A.; methodology, A.G.D.1.R., M.D.C. and I.M.-L.; software, A.G.D.1.R.; validation, A.G.D.1.R.; formal analysis, A.G.D.l.R.; investigation, A.G.D.1.R. and P.G.-A.; resources, M.D.C. and P.G.-A.; data curation, A.G.D.1.R., M.D.C. and I.M.-L.; writing —original draft preparation, A.G.D.1.R. and P.G.-A.; writing-review and editing, A.G.D.1.R., M.D.C., I.M.-L. and P.G.-A.; visualization, A.G.D.1.R.; supervision, P.G.-A.; project administration, P.G.-A.; funding acquisition, P.G.-A. All authors have read and agreed to the published version of the manuscript.
\end{abstract}

Funding: This research was funded by the Spanish Ministry of Economy, Industry and Competitiveness, grant number RTC-2016-5816-2. The APC was funded by a Ph.D. student grant from the Spanish Education Ministry (FPU17/05849).

Data Availability Statement: Not applicable.

Acknowledgments: We thank Hugo Mélida for critical reading of the manuscript and Rafael Calvo for the assistance with the English manuscript correction.

Conflicts of Interest: The authors declare no conflict of interest.

\title{
References
}

1. González, A.M.; Godoy, L.; Santalla, M. Dissection of Resistance Genes to Pseudomonas syringae pv. phaseolicola in UI3 Common Bean Cultivar. Int. J. Mol. Sci. 2017, 18, 2503. [CrossRef]

2. Arnold, D.L.; Lovell, H.C.; Jackson, R.W.; Mansfield, J.W. Pseudomonas syringae pv. phaseolicola: From "has bean" to supermodel. Mol. Plant Pathol. 2011, 12, 617-627. [CrossRef]

3. Asensio-S.-Manzanera, M.C.; Asensio, C.; Singh, S.P. Gamete selection for resistance to common and halo bacterial blights in dry bean intergene pool populations. Crop Sci. 2006, 46, 131-135. [CrossRef]

4. Zhang, S.; Fu, Y.; Mersha, Z.; Pernezny, K. Assessment of copper resistance in Pseudomonas syringae pv. phaseolicola, the pathogen of halo blight on snap bean. Crop Prot. 2017, 98, 8-15. [CrossRef]

5. Monteagudo, A.B.; Rodiño, A.P.; Lema, M.; De La Fuente, M.; Santalla, M.; De Ron, A.M.; Singh, S.P. Resistance to infection by fungal, bacterial, and viral pathogens in a common bean core collection from the Iberian Peninsula. HortScience 2006, 41, 319-322. [CrossRef]

6. De la Rubia, A.G.; Centeno, M.L.; Moreno-González, V.; De Castro, M.; García-Angulo, P. Perception and first defense responses against Pseudomonas syringae pv. phaseolicola in Phaseolus vulgaris L.: Identification of Wall-Associated Kinase receptors. Phytopathology 2021, 1-11. [CrossRef] [PubMed]

7. Martínez-Aguilar, K.; Ramírez-Carrasco, G.; Hernández-Chávez, J.L.; Barraza, A.; Alvarez-Venegas, R. Use of BABA and INA As Activators of a Primed State in the Common Bean (Phaseolus vulgaris L.). Front. Plant Sci. 2016, 7, 653. [CrossRef] [PubMed]

8. Ramírez-Carrasco, G.; Martínez-Aguilar, K.; Alvarez-Venegas, R. Transgenerational Defense Priming for Crop Protection against Plant Pathogens: A Hypothesis. Front. Plant Sci. 2017, 8, 696. [CrossRef] [PubMed]

9. De la Rubia, A.G.; Mélida, H.; Centeno, M.L.; Encina, A.; García-Angulo, P. Immune Priming Triggers Cell Wall Remodeling and Increased Resistance to Halo Blight Disease in Common Bean. Plants 2021, 10, 1514. [CrossRef]

10. Kauss, H.; Theisinger-Hinkel, E.; Mindermann, R.; Conrath, U. Dichloroisonicotinic and salicylic acid, inducers of systemic acquired resistance, enhance fungal elicitor responses in parsley cells. Plant J. 1992, 2, 655-660. [CrossRef]

11. Görlach, J.; Volrath, S.; Knauf-Beiter, G.; Hengy, G.; Beckhove, U.; Kogel, K.H.; Oostendorp, M.; Staub, T.; Ward, E.; Kessmann, H.; et al. Benzothiadiazole, a novel class of inducers of systemic acquired resistance, activates gene expression and disease resistance in wheat. Plant Cell 1996, 8, 629-643. [CrossRef] [PubMed]

12. Heil, M.; Hilpert, A.; Kaiser, W.; Linsenmair, K.E. Reduced growth and seed set following chemical induction of pathogen defence: Does systemic acquired resistance (SAR) incur allocation costs? J. Ecol. 2000, 88, 645-654. [CrossRef]

13. Boller, T.; Felix, G. A Renaissance of Elicitors: Perception of Microbe-Associated Molecular Patterns and Danger Signals by Pattern-Recognition Receptors. Annu. Rev. Plant Biol. 2009, 60, 379-406. [CrossRef] [PubMed]

14. Lotze, M.T.; Zeh, H.J.; Rubartelli, A.; Sparvero, L.J.; Amoscato, A.A.; Washburn, N.R.; DeVera, M.E.; Liang, X.; Tör, M.; Billiar, T. The grateful dead: Damage-associated molecular pattern molecules and reduction/oxidation regulate immunity. Immunol. Rev. 2007, 220, 60-81. [CrossRef]

15. Hou, S.; Liu, Z.; Shen, H.; Wu, D. Damage-Associated Molecular Pattern-Triggered Immunity in Plants. Front. Plant Sci. 2019, 10, 646. [CrossRef] [PubMed]

16. Voxeur, A.; Habrylo, O.; Guénin, S.; Miart, F.; Soulié, M.C.; Rihouey, C.; Pau-Roblot, C.; Domon, J.M.; Gutierrez, L.; Pelloux, J.; et al. Oligogalacturonide production upon Arabidopsis thaliana-Botrytis cinerea interaction. Proc. Natl. Acad. Sci. USA 2019, 116, 19743-19752. [CrossRef]

17. Mélida, H.; Bacete, L.; Ruprecht, C.; Rebaque, D.; Del Hierro, I.; López, G.; Brunner, F.; Pfrengle, F.; Molina, A. ArabinoxylanOligosaccharides Act as Damage Associated Molecular Patterns in Plants Regulating Disease Resistance. Front. Plant Sci. 2020, 11, 1210. [CrossRef] 
18. Mélida, H.; Sopeña-Torres, S.; Bacete, L.; Garrido-Arandia, M.; Jordá, L.; López, G.; Muñoz-Barrios, A.; Pacios, L.F.; Molina, A. Non-branched $\beta$-1,3-glucan oligosaccharides trigger immune responses in Arabidopsis. Plant J. 2018, 93, 34-49. [CrossRef]

19. Rebaque, D.; del Hierro, I.; López, G.; Bacete, L.; Vilaplana, F.; Dallabernardina, P.; Pfrengle, F.; Jordá, L.; Sánchez-Vallet, A.; Pérez, R.; et al. Cell wall-derived mixed-linked $\beta-1,3 / 1,4$-glucans trigger immune responses and disease resistance in plants. Plant J. 2021, 106, 601-615. [CrossRef]

20. Couto, D.; Zipfel, C. Regulation of pattern recognition receptor signalling in plants. Nat. Rev. Immunol. 2016, 16, 537-552. [CrossRef]

21. Smirnoff, N.; Arnaud, D. Hydrogen peroxide metabolism and functions in plants. N. Phytol. 2019, 221, 1197-1214. [CrossRef]

22. López-Moral, A.; Agustí-Brisach, C.; Trapero, A. Plant Biostimulants: New Insights into the Biological Control of Verticillium Wilt of Olive. Front. Plant Sci. 2021, 12, 782. [CrossRef]

23. Rakoczy-Lelek, R.; Smoleń, S.; Grzanka, M.; Ambroziak, K.; Pitala, J.; Skoczylas, Ł.; Liszka-Skoczylas, M.; Kardasz, H. Effectiveness of Foliar Biofortification of Carrot With Iodine and Selenium in a Field Condition. Front. Plant Sci. 2021, 12, 656283. [CrossRef] [PubMed]

24. Qiu, H.; Su, L.; Wang, H.; Zhang, Z. Chitosan elicitation of saponin accumulation in Psammosilene tunicoides hairy roots by modulating antioxidant activity, nitric oxide production and differential gene expression. Plant Physiol. Biochem. 2021, 166, 115-127. [CrossRef]

25. Shahrajabian, M.H.; Chaski, C.; Polyzos, N.; Tzortzakis, N.; Petropoulos, S.A. Sustainable Agriculture Systems in Vegetable Production Using Chitin and Chitosan as Plant Biostimulants. Biomolecules 2021, 11, 819. [CrossRef]

26. Barna, D.; Kisvarga, S.; Kovács, S.; Csatári, G.; Tóth, I.O.; Fári, M.G.; Alshaal, T.; Bákonyi, N. Raw and Fermented Alfalfa Brown Juice Induces Changes in the Germination and Development of French Marigold (Tagetes patula L.) Plants. Plants 2021, $10,1076$. [CrossRef]

27. El Boukhari, M.E.M.; Barakate, M.; Choumani, N.; Bouhia, Y.; Lyamlouli, K. Ulva lactuca Extract and Fractions as Seed Priming Agents Mitigate Salinity Stress in Tomato Seedlings. Plants 2021, 10, 1104. [CrossRef]

28. Zaynab, M.; Fatima, M.; Abbas, S.; Sharif, Y.; Umair, M.; Zafar, M.H.; Bahadar, K. Role of secondary metabolites in plant defense against pathogens. Microb. Pathog. 2018, 124, 198-202. [CrossRef]

29. Kadoglidou, K.; Chatzopoulou, P.; Maloupa, E.; Kalaitzidis, A.; Ghoghoberidze, S.; Katsantonis, D. Mentha and oregano soil amendment induces enhancement of tomato tolerance against soilborne diseases, yield and quality. Agronomy 2020, 10, 406. [CrossRef]

30. Latique, S.; Mrid, R.B.; Kabach, I.; Kchikich, A.; Sammama, H.; Yasri, A.; Nhiri, M.; El Kaoua, M.; Douira, A.; Selmaoui, K. Foliar Application of Ulva rigida Water Extracts Improves Salinity Tolerance in Wheat (Triticum durum L.). Agronomy 2021, 11, 265. [CrossRef]

31. Yusoff, S.F.; Haron, F.F.; Asib, N.; Mohamed, M.T.M.; Ismail, S.I. Development of Vernonia amygdalina Leaf Extract Emulsion Formulations in Controlling Gray Mold Disease on Tomato (Lycopersicon esculentum Mill.). Agronomy 2021, 11, 373. [CrossRef]

32. Bella, E.L.; Baglieri, A.; Rovetto, E.I.; Stevanato, P.; Puglisi, I. Foliar spray application of Chlorella vulgaris extract: Effect on the growth of lettuce seedlings. Agronomy 2021, 11, 308. [CrossRef]

33. Abdel Latef, A.A.H.; Zaid, A.; Alwaleed, E.A. Influences of Priming on Selected Physiological Attributes and Protein Pattern Responses of Salinized Wheat with Extracts of Hormophysa cuneiformis and Actinotrichia fragilis. Agronomy 2021, 11, 545. [CrossRef]

34. Schneider, C.A.; Rasband, W.S.; Eliceiri, K.W. NIH Image to ImageJ: 25 years of image analysis. Nat. Methods 2012, 9, 671-675. [CrossRef]

35. Largo-Gosens, A.; de Castro, M.; Alonso-Simón, A.; García-Angulo, P.; Acebes, J.L.; Encina, A.; Álvarez, J.M. Quinclorachabituation of bean (Phaseolus vulgaris) cultured cells is related to an increase in their antioxidant capacity. Plant Physiol. Biochem. 2016, 107, 257-263. [CrossRef]

36. Bradford, M. A Rapid and Sensitive Method for the Quantitation of Microgram Quantities of Protein Utilizing the Principle of Protein-Dye Binding. Anal. Biochem. 1976, 72, 248-254. [CrossRef]

37. Cheeseman, J.M. Hydrogen peroxide concentrations in leaves under natural conditions. J. Exp. Bot. 2006, 57, 2435-2444. [CrossRef]

38. Buege, J.A.; Aust, S.D. Microsomal Lipid Peroxidation. Methods Enzymol. 1978, 52, 302-310. [CrossRef]

39. Droillard, M.J.; Paulin, A.; Massot, J.C. Free radical production, catalase and superoxide dismutase activities and membrane integrity during senescence of petals of cut carnations (Dianthus caryophyllus). Physiol. Plant. 1987, 71, 197-202. [CrossRef]

40. Hossain, M.A.; Asada, K. Inactivation of ascorbate peroxidase in spinach chloroplasts on dark addition of hydrogen peroxide: Its protection by ascorbate. Plant Cell Physiol. 1984, 25, 1285-1295. [CrossRef]

41. Ádám, A.L.; Bestwick, C.S.; Barna, B.; Mansfield, J.W. Enzymes regulating the accumulation of active oxygen species during the hypersensitive reaction of bean to Pseudomonas syringae pv. phaseolicola. Planta 1995, 197, 240-249. [CrossRef]

42. Borges, A.; Tsai, S.M.; Caldas, D.G.G. Validation of reference genes for RT-qPCR normalization in common bean during biotic and abiotic stresses. Plant Cell Rep. 2012, 31, 827-838. [CrossRef] [PubMed]

43. Livak, K.J.; Schmittgen, T.D. Analysis of relative gene expression data using real-time quantitative PCR and the 2(-Delta Delta C(T)) Method. Methods 2001, 25, 402-408. [CrossRef] 
44. Guerrero-González, M.L.; Rodríguez-Kessler, M.; Rodríguez-Guerra, R.; González-Chavira, M.; Simpson, J.; Sanchez, F.; JiménezBremont, J.F. Differential expression of Phaseolus vulgaris genes induced during the interaction with Rhizoctonia solani. Plant Cell Rep. 2011, 30, 1465-1473. [CrossRef] [PubMed]

45. Mayo, S.; Gutiérrez, S.; Malmierca, M.G.; Lorenzana, A.; Campelo, M.P.; Hermosa, R.; Casquero, P.A. Influence of Rhizoctonia solani and Trichoderma spp. In growth of bean (Phaseolus vulgaris L.) and in the induction of plant defense-related genes. Front. Plant Sci. 2015, 6, 685. [CrossRef] [PubMed]

46. Sharma, P.; Jha, A.B.; Dubey, R.S.; Pessarakli, M. Reactive Oxygen Species, Oxidative Damage, and Antioxidative Defense Mechanism in Plants under Stressful Conditions. J. Bot. 2012, 2012, 217037. [CrossRef]

47. Pedre, B.; Young, D.; Charlier, D.; Mourenza, Á.; Rosado, L.A.; Marcos-Pascual, L.; Wahni, K.; Martens, E.; de la Rubia, A.G.; Belousov, V.V.; et al. Structural snapshots of OxyR reveal the peroxidatic mechanism of $\mathrm{H}_{2} \mathrm{O}_{2}$ sensing. Proc. Natl. Acad. Sci. USA 2018, 115, E11623-E11632. [CrossRef] [PubMed]

48. Breen, S.; Williams, S.J.; Outram, M.; Kobe, B.; Solomon, P.S. Emerging Insights into the Functions of Pathogenesis-Related Protein 1. Trends Plant Sci. 2017, 22, 871-879. [CrossRef]

49. Krofta, K.; Houška, M.; Mikyška, A.; Čermák, P. Changes in the composition of hop secondary metabolites induced by high hydrostatic pressure. J. Inst. Brew. 2018, 124, 158-172. [CrossRef]

50. Flythe, M.D. The antimicrobial effects of hops (Humulus lupulus L.) on ruminal hyper ammonia-producing bacteria. Lett. Appl. Microbiol. 2009, 48, 712-717. [CrossRef]

51. Pallag, A.; Filip, G.A.; Olteanu, D.; Clichici, S.; Baldea, I.; Jurca, T.; Micle, O.; Vicas, L.; Marian, E.; Sorițău, O.; et al. Equisetum arvense L. extract induces antibacterial activity and modulates oxidative stress, inflammation, and apoptosis in endothelial vascular cells exposed to hyperosmotic stress. Oxid. Med. Cell. Longev. 2018, 2018, 3060525. [CrossRef] [PubMed]

52. Rogozhin, E.A.; Vasilchenko, A.S.; Barashkova, A.S.; Smirnov, A.N.; Zavriev, S.K.; Demushkin, V.P. Peptide extracts from seven medicinal plants discovered to inhibit oomycete phytophthora infestans, a causative agent of potato late blight disease. Plants 2020, 9, 1294. [CrossRef] [PubMed]

53. Augspole, I.; Duma, M.; Ozola, B.; Cinkmanis, I. Phenolic profile of fresh and frozen netthle, goutweed, dandelion ad chickweed leaves. Foodbalt 2017, 36-39. [CrossRef]

54. Kregiel, D.; Pawlikowska, E.; Antolak, H. Urtica spp.: Ordinary plants with extraordinary properties. Molecules 2018, $23,1664$. [CrossRef] [PubMed]

55. Furiga, A.; Lonvaud-Funel, A.; Badet, C. In vitro study of antioxidant capacity and antibacterial activity on oral anaerobes of a grape seed extract. Food Chem. 2009, 113, 1037-1040. [CrossRef]

56. Costa, J.R.; Amorim, M.; Vilas-Boas, A.; Tonon, R.V.; Cabral, L.M.C.; Pastrana, L.; Pintado, M. Impact of: In vitro gastrointestinal digestion on the chemical composition, bioactive properties, and cytotoxicity of Vitis vinifera L. cv. Syrah grape pomace extract. Food Funct. 2019, 10, 1856-1869. [CrossRef] [PubMed]

57. Oliveira, D.A.; Salvador, A.A.; Smânia, A.; Smânia, E.F.A.; Maraschin, M.; Ferreira, S.R.S. Antimicrobial activity and composition profile of grape (Vitis vinifera) pomace extracts obtained by supercritical fluids. J. Biotechnol. 2013, 164, 423-432. [CrossRef] [PubMed]

58. Al-Mousawi, A.H.; Al-kaabi, S.J.; Albaghdadi, A.J.H.; Almulla, A.F.; Raheem, A.; Algon, A.A.A. Effect of Black Grape Seed Extract (Vitis vinifera) on Biofilm Formation of Methicillin-Resistant Staphylococcus aureus and Staphylococcus haemolyticus. Curr. Microbiol. 2020, 77, 238-245. [CrossRef] [PubMed]

59. Waszczak, C.; Carmody, M.; Kangasjärvi, J. Reactive Oxygen Species in Plant Signaling. Annu. Rev. Plant Biol. 2018, 69, 209-236. [CrossRef] [PubMed]

60. Dat, J.; Vandenabeele, S.; Vranová, E.; Van Montagu, M.; Inzé, D.; Van Breusegem, F. Dual action of the active oxygen species during plant stress responses. Cell. Mol. Life Sci. 2000, 57, 779-795. [CrossRef] [PubMed]

61. Gill, S.S.; Tuteja, N. Reactive oxygen species and antioxidant machinery in abiotic stress tolerance in crop plants. Plant Physiol. Biochem. PPB 2010, 48, 909-930. [CrossRef]

62. Mittler, R. ROS Are Good. Trends Plant Sci. 2017, 22, 11-19. [CrossRef]

63. Leonard, S.S.; Xia, C.; Jiang, B.H.; Stinefelt, B.; Klandorf, H.; Harris, G.K.; Shi, X. Resveratrol scavenges reactive oxygen species and effects radical-induced cellular responses. Biochem. Biophys. Res. Commun. 2003, 309, 1017-1026. [CrossRef] [PubMed]

64. Bakshi, M.; Oelmüller, R. Wrky transcription factors jack of many trades in plants. Plant Signal. Behav. 2014, 9, e27700. [CrossRef] [PubMed]

65. Kapos, P.; Devendrakumar, K.T.; Li, X. Plant NLRs: From discovery to application. Plant Sci. 2019, 279, 3-18. [CrossRef]

66. Van Loon, L.C.; Van Strien, E.A. The families of pathogenesis-related proteins, their activities, and comparative analysis of PR-1 type proteins. Physiol. Mol. Plant Pathol. 1999, 55, 85-97. [CrossRef]

67. Betsuyaku, S.; Katou, S.; Takebayashi, Y.; Sakakibara, H.; Nomura, N.; Fukuda, H. Salicylic Acid and Jasmonic Acid Pathways are Activated in Spatially Different Domains around the Infection Site during Effector-Triggered Immunity in Arabidopsis thaliana. Plant Cell Physiol. 2018, 59, 8-16. [CrossRef]

68. Van Loon, L.C.; Rep, M.; Pieterse, C.M.J. Significance of inducible defense-related proteins in infected plants. Annu. Rev. Phytopathol. 2006, 44, 135-162. [CrossRef]

69. Abo-Zaid, G.A.; Matar, S.M.; Abdelkhalek, A. Induction of plant resistance against tobacco mosaic virus using the biocontrol agent streptomyces cellulosae isolate actino 48. Agronomy 2020, 10, 1620. [CrossRef] 
70. Huot, B.; Yao, J.; Montgomery, B.L.; He, S.Y. Growth-defense tradeoffs in plants: A balancing act to optimize fitness. Mol. Plant 2014, 7, 1267-1287. [CrossRef]

71. Ning, Y.; Liu, W.; Wang, G.L. Balancing Immunity and Yield in Crop Plants. Trends Plant Sci. 2017, 22, 1069-1079. [CrossRef] [PubMed]

72. Lawton, K.A.; Friedrich, L.; Hunt, M.; Weymann, K.; Delaney, T.; Kessmann, H.; Staub, T.; Ryals, J. Benzothiadiazole induces disease resistance in Arabidopsis by activation of the systemic acquired resistance signal transduction pathway. Plant J. 1996, 10, 71-82. [CrossRef] [PubMed]

73. Maricic, B.; Radman, S.; Romic, M.; Perkovic, J.; Major, N.; Urlic, B.; Palcic, I.; Ban, D.; Zoric, Z.; Ban, S.G. Stinging Nettle (Urtica dioica L.) as an Aqueous Plant-Based Extract Fertilizer in Green Bean (Phaseolus vulgaris L.) Sustainable Agriculture. Sustainability 2021, 13, 4042. [CrossRef] 